\title{
ANALISIS FAKTOR-FAKTOR YANG MEMPENGARUHI KEPUTUSAN KONSUMEN MEMILIH PRODUK SYNGENTA ATAU NON SYNGENTA (KASUS PADA PETANI SAYUR DI KECAMATAN SELUPU REJANG KABUPATEN REJANG LEBONG)
}

\author{
Nyayu Neti Arianti ${ }^{1}$ \\ Basuki Sigit Priyono ${ }^{1}$ \\ Elsi Women ${ }^{2}$ \\ ${ }^{1}$ Staf Pengajar Jurusan Sosial Ekonomi Pertanian Fak. Pertanian UNIB \\ ${ }^{2}$ Alumni Jurusan Sosial Ekonomi Pertanian Fak. Pertanian UNIB
}

\begin{abstract}
This research aims are to know the reason of consumers chosen and the factors influencing decision of consumers chosen Syngenta or Non Syngenta product.This reseach was apllied at Selupu Rejang Sub district Rejang Lebong District. Analysis methods which used are descriptive analysis and quantitative analysis. Descriptive analysis that is giving common picture to reseach object, reasons pushing consumers to chosen and consume the Syngenta or Non Syngenta product, and also explain the proportion usage of insecticide, fungicide and haerbicide from Syngenta or Non Syngenta product. Quantitative analysis is to know the factors of influencing consumers decision in chosen Syngenta or Non Syngenta product by using regression model of logit. Result of analysis indicate that the reasons of consumers chosen Syngenta product are efective to use, good harvest, price reached, more use by the farmers. And than, the reasons of consumers chosen Non Syngenta product are efective to use, swafety to use, good harvest and more use by the farmers
\end{abstract}

Key words : influencing decision,consumer, chosen

\section{PENDAHULUAN}

Masyarakat Indonesia di pedesaan memenuhi kebutuhan hidupnya dengan cara melakukan kegiatan usahatani. Dalam berusahatani, khususnya usahatani sayuran, petani menggunakan pestisida untuk menanggulangi hama dan atau penyakit yang menyerang tanaman mereka (Semangun, 2000). Untuk mengendalikan serangan hama dan penyakit tersebut petani menggunakan pestisida. Pestisida dapat digunakan dengan cepat, sehingga dapat digunakan dalam keadaan darurat yaitu pada saat tanaman sudah terserang hama dan atau penyakit yang akan mencapai ambang kerusakan yang secara ekonomis akan merugikan (Himawan, 2004). 
Perusahaan yang memproduksi pestisida antara lain PT.Mikro, PT.Syngenta, PT.Bayer dan lain-lain (Wudianto, 1993). Pestisida yang diproduksi oleh PT. Syngenta antara lain adalah fungisida, herbisida dan insektisida (Briggs, 2000). Penggunaan pestisida pada tanaman sayur-sayuran berbeda dengan tanaman perkebunan. Pada tanaman perkebunan misalnya tanaman karet dan sawit biasanya rentan terhadap gulma. Sedangkan pada tanaman sayuran sangat rentan dengan penyakit dan hama pengganggu tanaman, seperti serangan jamur, ulat dan serangga (Semangun, 2000).

Salah satu daerah sentra produksi sayuran di provinsi Bengkulu adalah daerah Selupu Rejang Kabupaten Rejang Lebong. Di daerah ini petani banyak menanam berbagai jenis tanaman sayuran, antara lain kubis/kol, sawi, bawang daun dan lain-lain. Petani di daerah ini juga menghadapi serangan hama dan atau penyakit yang menyerang tanaman mereka. Untuk mengatasi masalah ini, petani dihadapkan pada pilihan produk pestisida dari berbagai macam perusahaan dengan beragam jenis pestisida yang ditawarkan. Seperti yang kita ketahui, pestisida memiliki fungsi yang berbeda-beda. Untuk tanaman sayursayuran biasanya petani memilih menggunakan fungisida dan insektisida. Karena pada tanaman sayur-sayuran sering terdapat fungi/jamur sebagai pengganggu di sekitar areal tanaman dan serangga yang menyerang tanaman (Semangun, 2000). Sehingga pada tanaman sayur-sayuran pemanfaatan pestisida yang lebih dominan adalah insektisida dan fungisida.

Keputusan dalam memilih untuk menggunakan produk dari perusahaan mana pada petani sayuran sangat tergantung pada faktor sosial ekonomi petani dan juga faktor psikologi petani tersebut. Petani tersebut akan menghadapi dilema dalam memilih produk pestisida, baik yang berasal dari perusahaan Syngenta atau perusahaan sejenis lainnya yang disebut Non Syngenta.adapun maksud dari penelitian ini adalah untuk mengetahui alasan 
konsumen memilih produk Syngenta atau Non Syngenta, proporsi penggunaan insektisida, herbisida dan fungisida dan faktor-faktor yang mempengaruhi keputusan konsumen memilih produk Syngenta atau Non Syngenta

\section{METODOLOGI PENELITIAN}

Untuk melakukan penelitian ini, peneliti mengambil tempat di retailer yang terbesar dan teramai yang berada di Pasar Atas Kota Curup, yaitu toko Tani Subur. Petanipetani yang ada di daerah Selupu Rejang pada umumnya membeli produk pestisida Syngenta atau Non Syngenta di retailer tersebut karena berada di jalan lintas menuju Kecamatan Selupu Rejang.

Penentuan responden dalam penelitian ini dilakukan dengan cara accidental sampling, yaitu teknik penentuan sampel berdasarkan kebetulan, namun tetap memperhatikan bahwa petani yang dipilih menjadi responden adalah petani yang berasal dari Kecamatan Selupu Rejang. Metode ini dipilih karena jumlah populasi yang menggunakan produk Syngenta atau Non Syngenta tidak diketahui. Responden yang diambil adalah petani yang menanam tanaman sayur-sayuran yang memilih produk Syngenta atau Non Syngenta sebanyak 100 orang. Di mana petani tersebut datang untuk membeli produk Syngenta atau Non Syngenta di retailer di Kota Curup.

Analisis data dilakukan dengan dua cara yaitu analisis kualitatif berupa:

Analisis deskriptif berupa penjelasan atau pembahasan data yang diperoleh selama penelitian dilaksanakan, yaitu menjelaskan alasan-alasan yang mendorong konsumen untuk memilih mengkonsumsi produk Syngenta atau Non Syngenta. Untuk mengetahui proporsi penggunaan pestisida, baik pestisida Syngenta atau Non Syngenta yang digunakan oleh responden dilakukan dengan perhitungan statistik. Adapun rumus yang digunakan adalah sebagai berikut: 
Proporsi penggunaan pestisida

$=\underline{\text { Jmlh pestisida yg digunakan }(\mathrm{gr}) \text { atau }(\mathrm{ml})} \times 100 \%$

Total pestisida yg digunakan (gr) atau (ml)

Pada pemilihan produk Syngenta atau Non Syngenta digunakan model regresi logit. Seperti halnya regresi linier, regresi logit juga menggambarkan variabel tak bebas dengan variabel bebas. Bedanya variabel tak bebas dalam regresi logit bersifat biner dikotomi yakni memiliki nilai yang kontinue 1 atau 0 .

Dalam kasus ini, penelitian dihadapkan pada pilihan produk Syngenta atau Non Syngenta. Keputusan dalam memilih salah satu jenis produk tersebut dianggap sebagai variabel tak bebas, yang diduga dipengaruhi oleh variabel bebas yakni tingkat pendidikan formal, tingkat pendidikan non formal, jumlah penerimaan keluarga, pengalaman berusahatani, luas lahan dan persepsi petani terhadap produk Syngenta.

Dimana :

$$
P i=\frac{n_{i}}{N}
$$

Keterangan:

$\mathrm{Pi}=$ Peluang konsumen memilih produk

$\mathrm{N}=$ Jumlah konsumen yang memilih produk Syngenta atau Non Syngenta

$\mathrm{ni}=$ Jumlah konsumen yang memilih produk Syngenta

Dengan nilai Pi diketahui maka nilai Li dapat ditaksir:

$$
\begin{aligned}
& \mathrm{Pi}=\mathrm{F}(\alpha+\beta \mathrm{x})=1 /\left(1+\mathrm{e}^{(-\alpha-\beta \mathrm{x})}\right) \\
& (1-\mathrm{Pi})=\mathrm{F}(\alpha+\beta \mathrm{x})=1 /\left(1+\mathrm{e}^{(\alpha+\beta \mathrm{x})}\right) \\
& \mathrm{Pi} /(1-\mathrm{Pi})=\left(1+\mathrm{e}^{(-\alpha-\beta \mathrm{x})}\right) /\left(1+\mathrm{e}^{(\alpha+\beta \mathrm{x})}\right) \\
& \mathrm{Li}=\mathrm{Ln}[\mathrm{Pi} /(1-\mathrm{Pi})]=\alpha+\beta \mathrm{i} \mathrm{X}_{\mathrm{i}}+\mathrm{Ui}
\end{aligned}
$$

Formula tersebut dapat juga ditulis sebagai berikut :

$$
\begin{aligned}
& \mathrm{Li}=\mathrm{Ln} \mathrm{Pi} /(1-\mathrm{Pi})=\beta+\beta \mathrm{i} \mathrm{X}_{\mathrm{i}}+\mathrm{Ui} \\
& \mathrm{L}=\beta_{0}+\beta_{1} \mathrm{X}_{1}+\beta_{2} \mathrm{X}_{2}+\beta_{3} \mathrm{X}_{3}+\beta_{4} \mathrm{X}_{4}+\beta_{5} \mathrm{X}_{5}+\beta_{6} \mathrm{D}+\mathrm{Ui}
\end{aligned}
$$

Keterangan:

$\mathrm{Li}=$ Pilihan produk Syngenta atau Non Syngenta 
$\mathrm{L}=$ Pilihan untuk jenis pestisida; dimana 1 untuk produk Syngenta, 0 untuk Non Syngenta

$\beta_{1 \ldots} \beta_{6} \quad=$ Koefisien regresi

$\beta_{0} \quad=$ Konstanta

$\mathrm{X}_{1}=$ Tingkat pendidikan formal (Tahun)

$\mathrm{X}_{2}=$ Tingkat pendidikan non formal (kali)

$\mathrm{X}_{3}=$ Jumlah penerimaan keluarga $(\mathrm{Rp} / \mathrm{Bln})$

$\mathrm{X}_{4}=$ Pengalaman berusahatani (Tahun)

$\mathrm{X}_{5}=$ Luas lahan $(\mathrm{Ha})$

$\mathrm{D}=$ Persepsi petani terhadap produk Syngenta $($ Baik $=1$, buruk $=0)$

$\mathrm{Ui}=$ Kesalahan pengganggu

Menurut Lestari (2005), untuk mengetahui apa yang menjadi persepsi petani terhadap pestisida baik Syngenta atau Non Syngenta dikemas dalam pertanyaanpertanyaan yang diukur dengan skor. Masing-masing pertanyaan diarahkan kepada tiga alternatif jawaban. Nilai skor tersebut berkisar antara 1 sampai 3. Dimana 1 untuk kurang baik, 2 untuk sedang, 3 untuk baik.

Rentang masing-masing katagori dapat diketahui dengan menggunakan rumus berikut :

Nilai atas - nilai bawah

Interval $=$

3 kelas

Dimana :

Nilai atas $=$ skor tertinggi (3) $\mathrm{x}$ jumlah pertanyaan

Nilai bawah $=$ skor terendah $(1) \times$ jumlah pertanyaan

Sehingga dapat dikatakan bahwa :

Persepsi petani baik $=1$, jika total skor $>$ rata-rata total skor

Persepsi petani buruk $=0$, jika total skor $\leq$ rata-rata total skor

Selanjutnya fungsi ini akan diuji dengan :

1. Uji F

Uji F digunakan untuk memperlihatkan kemampuan variabel bebas secara bersama-sama menjelaskan dari variabel tak bebas. 
$\mathrm{H}_{0}: \beta_{1}=\beta_{2}=\ldots=\beta_{6}=0$

Hi : sedikitnya ada satu $\beta_{i} \neq 0$

$\mathrm{i}=1,2, \ldots, 6$

Dimana :

F hitung $=\underline{\text { Jumlah kuadrat regresi } / \mathrm{k}}$

Jumlah kuadrat sisa/(n-k)

Dimana :

$$
\begin{aligned}
& \mathrm{n}=\text { Jumlah sampel } \\
& \mathrm{k}=\text { Jumlah variabel bebas }
\end{aligned}
$$

2. Uji t

Uji t pada model logit untuk melihat nyata atau tidaknya pengaruh variabel bebas dan tak bebas melalui nilai t hitung tiap variabel dengan jumlah kepercayaan $95 \%$.

Hipotesis yang diuji :

$$
\begin{aligned}
& \mathrm{H}_{0}: \beta_{1}, \beta_{2}, \ldots, \beta_{6}=0 \\
& \text { Hi : sedikitnya ada satu } \beta_{\mathrm{i}} \neq 0 \\
& \mathrm{i}=1,2, \ldots, 6
\end{aligned}
$$

$$
\begin{array}{cl}
\operatorname{Dimana}_{\text {hitung }} & =\frac{\boldsymbol{\beta}_{\boldsymbol{i}}}{\boldsymbol{S}_{\text {Kỉ }}} \\
\mathrm{S}_{\beta \mathrm{i}} & : \text { Standard error dari masing-masing variabel } \\
\mathrm{i} & : 1,2,3,4,5,6
\end{array}
$$

\section{HASIL DAN PEMBAHASAN}

\section{Alasan-alasan Konsumen Memilih Produk Syngenta atau Non Syngenta}

Dari hasil penelitian maka diketahui beberapa alasan petani dalam memilih pestisida baik Syngenta atau Non Syngenta. Beberapa alasan tersebut dapat dilihat pada tabel berikut:

Tabel 10. Alasan-alasan Konsumen Memilih Produk Syngenta atau Non Syngenta

No

Alasan

Petani Pemilih

Petani Pemilih

Pestisida Syngenta

Pestisida Non Syngenta

\begin{tabular}{cccc}
\multicolumn{2}{c}{ Pestisida Syngenta } & \multicolumn{2}{c}{ Pestisida Non Syngenta } \\
\hline \multirow{3}{*}{ Jumlah (Orang) } & Persentase & Jumlah & Persentase \\
\cline { 3 - 4 } & $(\%)$ & (Orang) & $(\%)$
\end{tabular}




\begin{tabular}{llcccc}
\hline & Ampuh membasmi & & & & \\
1 & OPT & 30 & 100 & 69 & 69 \\
2 & Aman digunakan & - & - & 45 & - \\
3 & Hasil Panen bagus & 20 & 67 & - & 96 \\
4 & Harga terjangkau & 22 & 73 & 67 & 69 \\
5 & Petani banyak pakai & 17 & 57 & 48 & \\
\hline
\end{tabular}

Sumber : Data Primer Diolah, 2007

Dengan demikian adanya perbedaan alasan antara petani yang memilih pestisida Syngenta atau Non Syngenta mempengaruhi keputusan petani tersebut dalam memilih pestisida yang akan petani gunakan.Dari uraian di atas diketahui beberapa alasan utama petani dalam memilih pestisida Syngenta atau Non Syngenta yaitu karena ampuh membasmi OPT, aman digunakan, mudah digunakan, harga terjangkau dan petani banyak yang menggunakan.

Dari tabel di atas dapat dilihat kelebihan dari produk pestisida Syngenta yaitu sangat cocok digunakan untuk usahatani sayuran dan penggunaannya lebih hemat. Harga produk pestisida Syngenta memang lebih mahal dari pada produk pestisida merk lainnya. Pestisida Syngenta sangat ampuh dalam membasmi hama dan penyakit yang menyerang tanaman sayuran. Dosis yang dianjurkan juga sesuai dengan kebutuhan tanaman, hama dan penyakit yang terkena semprotan racun tersebut akan mati dan tidak akan kembali lagi, sehingga petani tidak perlu terus-menerus melakukan penyemprotan terhadap tanaman. Hal ini akan sangat membantu petani karena penggunaan pestisida akan lebih hemat, baik hemat uang, hemat tenaga dan hemat waktu. Dengan menggunakan pestisida Syngenta tanaman akan terhindar dari serangan hama dan penyakit sehingga hasil produksi yang didapat oleh petani adalah hasil yang maksimal.

\section{Proporsi Penggunaan Pestisida Syngenta atau Non Syngenta}

Dari hasil penelitian diketahui bahwa petani di daerah Selupu Rejang dalam melakukan kegiatan usahataninya menggunakan pestisida Syngenta atau Non 
Syngenta. Untuk lebih jelasnya lagi mengenai penggunaan pestisida berdasarkan jenis dan bentuknya dapat dilihat pada tabel di bawah ini:

Tabel 11. Penggunaan Pestisida Berdasarkan Jenis dan Bentuknya

\begin{tabular}{cccccc}
\hline No & Jenis produk pestisida & \multicolumn{2}{c}{ Fungisida } & \multicolumn{2}{c}{ Insektisida } \\
\cline { 3 - 6 } & & Padat $(\mathrm{gr})$ & Cair $(\mathrm{ml})$ & Padat $(\mathrm{gr})$ & Cair $(\mathrm{ml})$ \\
\hline 1 & Syngenta & 1500 & 3700 & 4800 & 7710 \\
2 & Non Syngenta & 36400 & 0 & 0 & 16190 \\
\hline & Jumlah & 37900 & 3700 & 4800 & 23900 \\
\hline
\end{tabular}

Sumber : Data Primer Diolah, 2007

Pestisida yang diproduksi Syngenta atau Non Syngenta untuk jenis fungisida dan insektisida terdiri dari dua bentuk yaitu bentuk padat dan cair. Untuk jenis insektisida konsumen lebih banyak menggunakan insektisida dalam bentuk cair karena penggunaannya lebih mudah dan praktis, dosis yang digunakan juga tidak melebihi anjuran pakai karena tutup botol kemasan insektisida tersebut merupakan takaran untuk menghitung dosis yang harus petani gunakan. Sehingga tidak ada racun yang terbuang siasia. Penggunaannya juga mudah, petani tinggal mencampurkan larutan racun tersebut dengan sejumlah air (sesuai petunjuk cara pakai), kemudian disemprotkan pada tanaman yang terseng hama dan penyakit, penyemprotan dapat menggunakan tangki penyemprotan. Untuk jenis fungisida petani lebih banyak memilih dalam bentuk padat, karena penggunaannya mudah, tinggal ditebar pada tanah di mana tanaman yang terseng hama dan penyakit tersebut tumbuh.

Untuk lebih jelasnya mengenai proporsi penggunaan pestisida berdasarkan bentuknya dapat dilihat pada perhitungan di bawah ini yang dihitung dalam bentuk persentase pemakaian beberapa jenis pestisida tersebut baik dari Syngenta maupun Non Syngenta. Adapun rumus yang digunakan adalah sebagai berikut:

Proporsi penggunaan pestisida $=\underline{\text { Jumlah pestisida yang digunakan }(\mathrm{gr}) \text { atau }(\mathrm{ml})} \mathrm{X} 100 \%$

Total pestisida yang digunakan $(\mathrm{gr})$ atau $(\mathrm{ml})$ 
Proporsi penggunaan produk Syngenta untuk jenis fungisida ada dua bentuk yaitu padat dan cair. Petani yang membeli fungisida berjumlah 11 orang, yang membeli fungisida padat berjumlah 3 orang atau $23,81 \%$, dan yang membeli fungisida cair sebanyak 8 orang atau 32,43\%. Petani yang membeli insektisida berjumlah 19 orang, yang membeli insektisida dalam bentuk padat sebanyak 4 orang atau $76,19 \%$, yang membeli dalam bentuk cair sebanyak 15 orang atau $67,57 \%$. Jadi penggunaan jenis produk Syngenta yang paling banyak adalah insektisida.

Proporsi penggunaan produk Non Syngenta untuk jenis fungisida yaitu padat. Petani yang membeli fungisida padat berjumlah 33 orang atau $100 \%$. Petani yang membeli insektisida berjumlah 38 orang, petani tersebut semuanya membeli dalam bentuk cair atau $100 \%$. Jadi penggunaan jenis produk Non Syngenta yang paling banyak adalah insektisida dan fungisida sama banyak digunakan.

Dari uraian di atas dapat disimpulkan bahwa proporsi penggunaan pestisida di daerah Selupu Rejang lebih banyak menggunakan jenis insektisida dari Syngenta dan jenis fungisida dan insektisida dari Non Syngenta. Penggunaan pestisida Syngenta yang terbanyak yaitu jenis insektisida padat dengan persentase $76,19 \%$. Untuk produk pestisida Non Syngenta, baik jenis fungisida dan insektisida adalah sama-sama banyak digunakan, yaitu dengan persentase sebesar $100 \%$. Sedangkan untuk tanaman perkebunan, hama dan penyakit yang lebih sering menyerang tanaman adalah serangan gulma dan serangga. Tanaman perkebunan memiliki daya tumbuh yang lebih tinggi daripada tanaman sayuran sehingga gulma dapat tumbuh bebas di bawah tanaman tersebut. Untuk membasmi serangan serangga, petani menggunakan pestisida. Dengan demikian petani tanaman perkebunan lebih banyak menggunakan herbisida dan insektisida dan untuk tanaman sayuran petani lebih memilih menggunakan pestisida jenis fungisida dan insektisida. 
Faktor-faktor yang Mempengaruhi Keputusan Konsumen Memilih Produk

\section{Syngenta atau Non Syngenta}

Untuk mengetahui pengaruh faktor pendidikan formal, pendidikan non formal, penerimaan keluarga, pengalaman berusahatani, luas lahan dan persepsi petani terhadap produk Syngenta terhadap pengambilan keputusan konsumen dalam memilih produk Syngenta atau Non Syngenta dapat dilihat pada tabel berikut:

Tabel 14. Hasil Estimasi pada Faktor-faktor yang Mempengaruhi Keputusan Konsumen Memilih Produk Syngenta atau Non Syngenta

\begin{tabular}{|c|c|c|c|c|c|}
\hline \multicolumn{2}{|c|}{ Variabel bebas } & $\begin{array}{l}\text { Koefisien } \\
\text { regresi }\end{array}$ & $\mathrm{Se}(\mathrm{bi})$ & t hitung & $\begin{array}{r}\mathrm{K} \epsilon \\
\mathrm{t}\end{array}$ \\
\hline \multicolumn{2}{|c|}{ Pendidikan formal (X1) } & $-0,27491$ & 0,25863 & $-1,0630$ & \\
\hline \multicolumn{2}{|c|}{ Pendidikan non formal (X2) } & 1,0669 & 0,64189 & 1,6622 & \\
\hline \multicolumn{2}{|c|}{ Penerimaan keluarga (X3) } & -0.000030044 & 0,00003399 & 088385 & \\
\hline \multicolumn{2}{|c|}{ Pengalaman berusahatani (X4) } & 0,089143 & 0,082427 & 1,0815 & \\
\hline \multicolumn{2}{|c|}{ Luas lahan (X5) } & $-0,98518$ & 0,94898 & $-1,0381$ & \\
\hline \multicolumn{2}{|c|}{$\begin{array}{l}\text { Persepsi petani terhadap produk Syngenta } \\
\text { (D) }\end{array}$} & 3,1565 & 1,0101 & 3,1248 & * \\
\hline Konstanta & $=-0,31857$ & & & & \\
\hline $\mathrm{R}^{2}$ & $=0,59422$ & & & & \\
\hline $\mathrm{t}$ tabel & $=+/-1,960$ & & & & \\
\hline F tabel & $=2,215$ & & & & \\
\hline F hitung & $=3,2905$ & & & & \\
\hline Keterangan $(*$ & $=$ Berpengaruh nyata pad & araf kepercayaa & $95 \%$ & & \\
\hline
\end{tabular}

Dari hasil analisis di atas dapat diketahui bahwa secara bersama-sama variabel pendidikan formal, pendidikan non formal, penerimaan keluarga, pengalaman berusahatani, luas lahan dan persepsi petani terhadap produk Syngenta mempengaruhi keputusan petani dalam memilih produk pestisida Syngenta atau Non Syngenta, dengan F hitung sebesar $(3,2905)$ lebih besar daripada F tabel $(2,215)$ pada taraf kepercayaan $95 \%$. Hal ini berarti keputusan konsumen dalam memilih produk Syngenta atau Non Syngenta secara nyata dipengaruhi oleh perubahan nilai variabel-variabel di atas. 
Pengaruh masing-masing variabel yang diteliti pada penelitian ini terhadap pemilihan petani untuk memilih produk Syngenta atau Non Syngenta akan dijelaskan secara rinci sebagai berikut:

\section{Pendidikan Formal}

Pendidikan formal tidak berpengaruh nyata terhadap keputusan konsumen memilih produk Syngenta atau Non Syngenta, dimana nilai t hitung $(-1,0630)$ lebih besar dari pada -t tabel $(-1,960)$, H0 diterima atau Ha ditolak.

Pendidikan formal tidak berpengaruh nyata karena tingkat pendidikan formal tidak selalu dapat merubah pemikiran atau pemahaman petani, terutama dalam hal keputusan memilih produk Syngenta atau Non Syngenta. Petani tidak membutuhkan pengetahuan dari pendidikan formal untuk memilih salah satu pestisida yang akan petani gunakan, melainkan ilmu yang diperoleh dari kegiatannya sehari-hari sebagai petani, karena dalam menjalankan usahataninya petani menemui berbagai hambatan seperti serangan hama dan penyakit pada tanaman sayuran dan cara penanggulangannya yang lebih tepat. Cara penanggulangan tersebut tidak didapat dibangku pendidikan formal. Seperti yang kita ketahui ilmu yang di dapat di bangku pendidikan formal sering tidak sesuai dengan kenyataan yang ditemui di lapangan.

\section{Pendidikan Non Formal}

Pendidikan non formal tidak berpengaruh nyata terhadap keputusan konsumen dalam memilih produk Syngenta atau Non Syngenta. Di mana nilai t hitung $(1,6622)$ lebih kecil daripada t tabel $(1,960)$ maka Ho diterima atau Ha ditolak. Hal ini menunjukkan bahwa walaupun petani telah mengikuti pendidikan non formal tetapi tidak membantu petani dalam mengambil keputusan memilih produk Syngenta atau Non Syngenta. Pelatihan yang diikuti oleh petani tersebut tidak mengangkat masalah pestisida baik 
pestisida Syngenta atau Non Syngenta. Pelatihan dan penyuluhan yang diikuti oleh petani tersebut antara lain mengenai pertanian yang ramah lingkungan atau pertanian organik, pelatihan pembuatan pupuk dengan metode EM4. Selain itu pada saat penelitian dilakukan ternyata kegiatan penyuluhan-penyuluhan oleh PT. Syngenta kurang dilakukan sehingga petani kurang mendapatkan informasi mengenai produk-produk pestisida Syngenta, pihak Syngenta biasanya melakukan pertemuan dengan petani yang menjadi petani binaan mereka pada suatu tempat/desa dan petani yang diutamakan untuk diundang adalah petani yang menjadi binaan PT. Syngenta

Petani yang menjadi responden tidak ada yang mengaku sebagai petani binaan PT. Syngenta, sehingga mereka kurang mengetahui informasi mengenai produk-produk pestisida Syngenta.

\section{Jumlah Penerimaan Keluarga}

Penerimaan keluarga tidak berpengaruh nyata terhadap keputusan konsumen memilih produk Syngenta atau Non Syngenta, dimana nilai t hitung $(-0,88385)$ lebih besar daripada - t tabel $(-1,960)$, maka Ho diterima atau Ha ditolak. Hal ini menunjukkan bahwa petani dalam memilih pestisida Syngenta atau Non Syngenta tidak tergantung pada jumlah penerimaan. Petani dengan jumlah penerimaan tinggi ada yang memilih menggunakan pestisida Syngenta dan juga ada yang memilih menggunakan pestisida Non Syngenta. Namun ada juga petani dengan penerimaan keluarga yang rendah memilih untuk menggunakan pestisida Syngenta dan ada juga yang memilih menggunakan pestisida Syngenta. Dengan demikian keputusan petani untuk menggunakan salah satu pestisida tersebut tidak dapat ditentukan oleh jumlah penerimaan keluarga.

\section{Pengalaman berusahatani}


Dari hasil regresi diketahui bahwa t hitung $(1,0815)$ lebih besar daripada t tabel (1,960), maka Ho diterima atau Ha ditolak, artinya pengalaman berusahatani tidak berpengaruh nyata terhadap keputusan konsumen dalam memilih produk Syngenta atau Non Syngenta. Ketika petani banyak menggunakan salah satu merk pestisida dan berhasil maka petani lain akan mengikuti jejak petani tersebut untuk menggunakan pestisida yang ia gunakan misalnya petani A menggunakan pestisida dengan merk Score untuk usahataninya dan berhasil, maka petani lain yang mendengar keberhasilan petani A akan mengikuti jejak petani A yaitu dia akan menggunakan Score juga untuk usahataninya. Petani tersebut berharap dengan menggunakan pestisida yang sama maka ia juga akan mendapatkan keberhasilan yang sama petani A. Petani tersebut tidak mengetahui pestisida tersebut cocok atau tidak digunakan pada lahan yang digarapnya. Hal ini karena petani cenderung mengikuti arus atau trend dalam menggunakan pestisida. Ketika petani melihat kekurangan pada suatu pestisida ataupun kelebihan pestisida lain maka petani dapat dengan cepat berpindah untuk memilih pestisida lain. Dengan kata lain pengalaman berusahatani seorang petani tidak dapat menunjukkan kesetiaan petani tersebut dalam menggunakan pestisida tertentu.

\section{Luas Lahan}

Dari hasil uji statistik yang dilakukan diketahui bahwa luas lahan tidak berpengaruh nyata terhadap keputusan konsumen dalam memilih produk Syngenta atau Non Syngenta, dimana nilai t hitung $(-1,0381)$ lebih besar daripada - $t$ tabel $(-1,960)$, maka Ho diterima atau Ha ditolak. Luas atau tidaknya lahan yang digarap petani tidak akan mempengaruhi pestisida yang akan ia gunakan. Harga pestisida Syngenta relative mahal daripada harga pestisida Non Syngenta. Petani dengan luasan lahan tertentu memiliki kemampuan untuk membeli pestisida Syngenta meskipun dengan harga yang relatif mahal, tetapi petani yang 
juga memiliki lahan garapan yang lebih luas lagi memiliki kemampuan yang lebih rendah untuk membeli pestisida Syngenta karena semakin luas lahan yang garap petani maka kebutuhan akan pestisida juga akan semakin banyak pula sementara kemampuan untuk membeli pestisida tersebut relatif kurang karena mahal harganya. Dengan demikian luas atau tidaknya lahan yang digarap petani tidak menentukan kemampuan petani dalam memilih salah satu pestisida baik Syngenta atau Non Syngenta.

\section{Persepsi Petani terhadap Produk Syngenta}

Dari hasil analisa statistik diketahui bahwa persepsi petani terhadap produk Syngenta berpengaruh nyata terhadap keputusan konsumen dalam memilih pestisida Syngenta atau Non Syngenta, dimana nilai t hitung $(3,1248)$ lebih besar dari nilai t tabel (1,960), maka Ho ditolak atau Ha diterima. Artinya persepsi petani terhadap produk Syngenta mempengaruhi keputusan konsumen dalam memilih pestisida Syngenta atau Non Syngenta.

Persepsi adalah proses bagaimana seseorang menyeleksi, mengatur dan menginterprestasikan masukan-masukan informasi untuk menciptakan gambar keseluruhan yang berarti. Persepsi petani terhadap produk pestisida dapat dilihat dari kualitas, mutu produk dan harga produk. Persepsi merupakan penilaian atau tanggapan petani terhadap produk Syngenta. Semakin baik persepsi petani terhadap produk pestisida Syngenta maka petani tersebut akan memilih menggunakan pestisida Syngenta, sebaliknya semakin buruk persepsi petani terhada pestisida Syngenta maka petani tersebut akan memilih menggunakan pestisida Non Syngenta. Hal ini tidak sejalan dengan hasil penelitian Juita (2005), persepsi petani terhadap teknologi PTT tidak berhubungan nyata dengan tingkat adopsi teknologi PTT. Baik atau kurang baiknya penilaian petani terhadap teknologi PTT tidak ada hubungannya dengan teknologi yang diterapkan oleh petani. Namun hasil uji 
tersebut sejalan dengan hasil penelitian Widodo (2004) yang mengatakan petani di desa Teras Terunjam memiliki persepsi atau penilaian yang baik terhadap usahatani yang dilakukan, dimana sebagian besar petani memiliki pandangan yang baik terhadap usahatani jagung

\section{KESIMPULAN DAN SARAN}

\section{Kesimpulan}

Berdasarkan hasil penelitian maka dapat disimpulkan bahwa :

1. Alasan-alasan konsumen memilih pestisida Syngenta atau Non Syngenta yaitu karena ampuh membasmi OPT, karena harga terjangkau, karena hasil panen bagus, karena petani banyak yang pakai, karena mudah digunakan, karena diajak/saran teman dan alasan lain-lainnya.

2. Proporsi penggunaan pestisida yang digunakan baik produk Syngenta atau Non Syngenta adalah untuk produk Syngenta jenis Fungisida padat sebesar 23,81\% dan cair sebesar 32,43\%, insektisida padat sebesar 76,19\% dan cair sebesar 67,57\%. Untuk produk Non Syngenta jenis Fungisida padat sebesar $100 \%$ dan insektisida cair sebesar $100 \%$.

3. Faktor yang mempengaruhi keputusan konsumen memilih pestisida Snyangenta atau Non Syngenta adalah persepsi petani terhadap pestisida Syngenta.

\section{Saran}

Dalam pengambilan keputusan konsumen untuk memilih produk Syngenta, maka pihak Syngenta perlu meningkatkan penyelenggaraan penyuluhan-penyuluhan dan pelatihan-pelatihan dan juga perlu melakukan promo khusus mengenai produk-produk Syngenta supaya produk tersebut lebih dikenal oleh petani. Selain itu perusahaan dan juga pihak distributor perlu memperhatikan keinginan dan kebutuhan petani akan pestisida baik 
dari segi jenis dan juga bentuknya khususnya untuk tanaman sayuran atau hortikultura, supaya tidak terjadi penumpukan barang yang akan mengakibatkan kerugian pada perusahaan.

\section{DAFTAR PUSTAKA}

Briggs, Henry F. 2000. Buku Informasi Produk Syngent. Syngenta. Jakarta

Himawan, Toto. 2004. Penerapan Teknologi Pestisida Alami. Makalah Disampaikan pada Pelatihan Dosen PTN/PTS Se-Indonesia di Malang 22-31 Mei 2004. Malang

Juita, Ermida. 2005. Faktor-faktor yang Penentu Tingkat Adopsi Teknologi Pengelolaan Tanaman dan Sumberdaya Terpadu (PTT) pada Usahatani Padi Sawah di Desa Rimbo Kedui Kecamatan Seluma Selatan Kabupaten Seluma. Skripsi Jurusan Sosial Ekonomi Pertanian. Fakultas Pertanian. Universitas Bengkulu. Bengkulu. (Tidak dipublikasikan)

Lestari, W. 2005. Analisis Faktor-faktor yang Berhubungan dengan Perilaku Petani dalam menggunakan Pupuk Organik pada Kegiatan Usahatani (Kasus di Desa Sumber Urip Kec. Selupu Rejang dan Desa Air Bang Kec. Curup Kab.R/L). Skripsi Jurusan Sosial Ekonomi Pertanian. Fakultas Pertanian. Universitas Bengkulu. Bengkulu. (Tidak dipublikasikan)

Semangun, Haryono. 2000. Penyakit-penyakit Tanaman Hortikultura di Indonesia. UGM Press Yogyakarta

Widodo, Hendri. 2004. Faktor-faktor yang Berhubungan dengan Tingkat Adopsi Teknologi usahatani Jagung Program BRDP (Bengkulu Regional Development Project) di Desa Teras Terunjam Kecamatan Teras terunjam Kabupaten Mukomuko. Skripsi Jurusan Sosial Ekonomi Pertanian. Fakultas Pertanian. Universitas Bengkulu. Bengkulu. (Tidak dipublikasikan)

Wudianto. Rini. 2004. Petunjuk Penggunaan Pestisida. Penebar Swadaya. Jakarta 